\title{
HUBUNGAN KEAKTIFAN BERTANYA DENGAN KECENDERUNGAN BERPIKIR KRITIS SISWA KELAS XI IPA DI SMA/MA SE-KECAMATAN NARMADA TAHUN AJARAN 2019/2020
}

\author{
Mutia Zahranie*, Yayuk Andayani, I Nyoman Loka \\ Program Studi Pendidikan Kimia, Universitas Mataram. Jalan Majapahit No. 62 \\ Mataram, NTB 83112, Indonesia. \\ * Coressponding Author. E-mail: mutiazahranie89@gmail.com
}

Received: 25 Oktober 2019

Accepted: 15 Mei 2020

Publish: 29 Mei 2020

doi: 10.29303/cep.v3i1.1426

\begin{abstract}
Abstrak
Penelitian ini bertujuan untuk mengetahui ada atau tidak ada hubungan antara keaktifan bertanya dengan kecenderungan berpikir kritis siswa kelas XI IPA di SMA/MA se-kecamatan Narmada Tahun Ajaran 2019/2020. Jenis penelitian yang digunakan adalah penelitian kuantitatif expost facto. Populasi dalam penelian ini meliputi seluruh siswa kelas XI IPA SMA Negeri 1 Narmada, SMA Negeri 2 Narmada, MAS Hikmatussyarief NW Salut, dan SMA NW Narmada yang berjumlah 338 siswa. Teknik yang digunakan untuk pengambilan sampel yaitu dengan menggunakan teknik Proportional Random Sampling. Sampel pada penelitian ini sebanyak 180 siswa yang dihitung menggunakan rumus Isaac dan Michael dengan taraf kesalahan $5 \%$. Pengambilan data keaktifan bertanya dan data kecenderungan berpikir kritis menggunakan angket. Teknik analisis data menggunakan statistik inferensial. Hasil uji hipotesis korelasi Product Moment regresi diperoleh koefisien korelasi sebesar 0,3382 lebih besar daripada $\mathrm{r}_{\text {tabel }} 0,1455$ pada taraf signifikan $5 \%$, yang menunjukkan bahwa terdapat hubungan antara keaktifan bertanya dengan kecenderungan berpikir kritis. Adapun kontribusi keaktifan bertanya terhadap kecenderungan berpikir kritis sebesar 11,43\%. Diperoleh persamaan regresi yaitu $\mathrm{Y}=44,55+0,146 \mathrm{X}$. Berdasarkan hasil tersebut maka dapat disimpulkan bahwa terdapat hubungan yang positif dan signifikan antara keaktifan bertanya dengan kecenderungan berpikir kritis siswa kelas XI IPA di SMA/MA se-kecamatan Narmada tahun ajaran 2019/2020.
\end{abstract}

Kata Kunci : Keaktifan bertanya, Kecenderungan berpikir kritis

\section{Correlation Between Frequency of Asking Questions and Critical Thinking Tedency $11^{\text {th }}$ Grade Students from Senior High Schools in Narmada Regency}

\begin{abstract}
This study aimed to find out the correlation between frequency of asking questions and critical thinking tedency 11th grade students from high school in Narmada regency class of 2019/2020. This research was ex-post facto quantitative study. The population of this study were 338 students of 11th grade students from SMAN 1 Narmada, SMAN 2 Narmada, MAS Hikmatussyarief NW Salut, and MA NW Narmada. The technique used in this research was Proportional Random Sampling. The samples were 180 students counted using Isaac dan Michael formula with $\alpha 5 \%$. The data of asking question frequency and critical thinking tedency was gained through questionnaire. The data were analyzed using inferensial technique. The hypothesis result of Product Moment Correlation was 0,3382 greater than $r_{\text {table }} 0,1455$ at $\alpha 5 \%$, which indicated the correlation between frequency of asking questions and critical thinking tedency. The contribution of asking question frequency and critical thinking skill was $11,43 \%$. The regression equation was $Y=44,55+0,146 X$. In conclusion, according to this results it can be concluded that there was a positive and significant correlation between frequency of asking questions and critical thinking tedency 11th grade students from high school in narmada regency class of 2019/2020.
\end{abstract}

Keywords : frequency of asking questions, critical thinking tedency 


\section{PENDAHULUAN}

Pendidikan yang berkualitas ditunjukkan dengan dihasilkan peserta didik yang memiliki keterampilan-keterampilan yang sesuai dengan tuntutan perkembangan zaman. Keterampilanketerampilan tersebut tentu baru dapat dikuasai oleh peserta didik jika keterampilan tersebut selalu dilatih diasah melalui proses pembelajaran. Menurut RAND Corporation (2012) dalam Mayasari, dkk (2016) ada sembilan kriteria pembelajaran yang mampu melatihkan keterampilan abad 21 yaitu: kurikulum yang relevan dengan keseharian peserta didik, pembelajaran yang melibatkan berbagai disiplin ilmu, mengembangkan keterampilan berpikir kritis, menerapkan pengetahuan yang diperoleh ke area lain atau disiplin ilmu lainnya yang bersinggungan dengan kehidupan sehari-hari peserta didik, membelajarkan bagaimana cara belajar kepada peserta didik, pembelajaran yang menangkal miskonsepsi, pembelajaran dalam tim, memanfaatkan teknologi untuk mendukung pembelajaran, mendorong kreativitas peserta didik.

Delphi $\begin{array}{cc}\text { Konsensus para ahli menggunakan The } \\ \text { Research Method telah }\end{array}$ mempublikasikan kesatuan persepsi mengenai berpikir kritis. Mereka membagi berpikir kritis menjadi dua komponen yaitu cognitive skill (keterampilan kognitif) dan dispositions (kecenderungan berpikir kritis). Keterampilan kognitif merupakan komponen yang sangat profundal, merupakan inti dari berpikir kritis yang dijabarkan menjadi interpretation, anlysis, evaluation, inference, explanation, dan self regulation. Kecenderungan berpikir kritis dideskripsikan sebagai semangat kekritisan atau kecendrungan untuk berpikir kritis yang memiliki karakteristik keingintahuan mendalam, ketajaman pemikiran, ketekunan mengembangkan akal, kebutuhan atas informasi yang dapat dipercaya (Facione, 2011).

Menurut penelitian yang dilakukan oleh Ramdani dan Badriah (2018) menyatakan bahwa terdapat korelasi antara kemampuan berpikir kritis dengan hasil belajar. Hal ini dapat dibuktikan dengan didapatkan nilai signifikansi linearitas sebesar 0,324 dan untuk persamaan regresi adalah $\mathrm{Y}=\mathrm{a}+\mathrm{bX}$. Nilai a adalah 61,678 dan nilai $b$ adalah 0,270 . Kemampuan berpikir kritis siswa di sekolah SMA Negeri 1 Narmada, SMA Negeri 2 Narmada, MAS Hikmatussyarief NW Salut dan SMA NW Narmada tergolong dalam katagori rendah yang dapat dilihat dari hasil belajar siswa yang rendah pada semester genap tahun pelajaran 2018/2019. Berikut ini nilai rata-rata UAS mata pelajaran kimia di SMA Negeri 1 Narmada, SMA Negeri 2 Narmada, SMA NW Narmada, dan MAS Hikmatussyarief NW Salut.

Tabel 1. Nilai Rata-Rata UAS Tahun Pelajaran 2018/2019

\begin{tabular}{clc}
\hline No & \multicolumn{1}{c}{ Nama Sekolah } & $\begin{array}{c}\text { Nilai Rata- } \\
\text { Rata }\end{array}$ \\
\hline 1 & SMAN 1 Narmada & 42,12 \\
2 & SMAN 2 Narmada & 58,32 \\
3 & MAS Hikmatussyarief & 81,02 \\
& NW Salut & 62,76 \\
4 & SMA NW Narmada & \multicolumn{2}{c}{ (Sumber: Arsip guru kimia SMA Negeri 1 }
\end{tabular}

Narmada, SMA Negeri 2 Narmada, SMA NW

Narmada, dan MAS Hikmatussyarief NW Salut)

Hasil data tabel di atas, terlihat hanya ada satu sekolah dari empat sekolah yang nilai rata-rata UASnya mencapai KKM. Hal ini menunjukkan bahwa kemampuan berpikir kritis siswa masih dalam katagori rendah, yang dapat menyebabkan hasil belajar siswa yang rendah. Kemampuan berpikir kritis siswa yang rendah disebabkan oleh kecenderungan berpikir kritis siswa yang rendah pula, karena kecenderungan berpikir kritis merupakan salah satu pendorong siswa untuk memiliki kemampuan berpikir kritis. Hal ini dibuktikan oleh hasil penelitian yang dilakukan oleh Andayani (2018) menunjukkan adanya hubungan yang positif dan signifikan antara kecenderungan berpikir kritis dengan keterampilan berpikir kritis.

Bertanya adalah cara penyampaian suatu pelajaran melalui interaksi dua arah yaitu dari guru kepada siswa dan dari siswa kepada guru agar diperoleh jawaban kepastian materi melalui jawaban lisan guru atau siswa. Hasil observasi awal di sekolah SMA Negeri 1 Narmada, SMA Negeri 2 Narmada, SMA NW Narmada, dan MAS Hikmatussyarief NW Salut, diketahui bahwa siswa sangat pasif ketika kegiatan pembelajaran berlangsung. Ketika guru memberikan kesempatan untuk bertanya tentang materi yang belum dipahami, hanya 2 sampai 5 siswa yang mengajukan pertanyaan. Hal ini dianggap oleh guru bahwa siswa sudah memahami materi pembelajaran yang telah diberikan. Hal tersebut dapat dipengaruhi oleh banyak faktor. Faktor tersebut terdiri atas faktor dari dalam diri siswa dan faktor dari luar diri 
siswa. Faktor dari dalam diri siswa meliputi minat siswa dalam bertanya, adanya perasaan tidak/ kurang berani dalam bertanya, motif keingintahuan siswa. Faktor dari luar diri siswa meliputi faktor guru (motivasi dari guru), dan faktor lingkungan, seperti suasana belajar (Royani, 2015).

Bertanya memiliki tujuan yaitu meningkatkan perhatian dan rasa ingin tahu siswa terhadap suatu topik dan pengetahuan baru, mengembangkan kemampuan berpikir kritis siswa, mengembangkan refleksi dan komentar siswa siswa terhadap pendapat siswa lain maupun guru. Dalam tujuan keaktifan bertanya tersebut terdapat beberapa indikator dari kecenderungan berpikir kritis yang menjadi tolak ukur untuk meningkatkan kecenderungan berpikir kritis siswa. Dengan begitu bertanya dapat mencerminkan bahwa siswa tersebut memiliki kecenderungan berpikir kritis (Hughes, 2003).

Berdasarkan uraian di atas, maka peneliti memilih judul penelitian tentang "Hubungan Keaktifan Bertanya dengan Kecenderungan Berpikir Kritis Siswa Kelas XI IPA di SMA/MA Se-Kecamatan Narmada Tahun Ajaran 2019/2020".

\section{METODELOGI PENELITIAN}

Penelitian ini dilakukan dengan tiga tahap yaitu tahap pertama melakukan perencanaan pada bulan Desember 2018, tahap kedua merupakan tahap persiapan dan pelaksanaan pada bulan Juli 2019, tahap ketiga merupakan tahap analisis data dan penulisan laporan dalam rangka menyusun tugas akhir atau skripsi pada bulan Juli 2019 hingga selesai. Penelitian ini dilaksanakan di empat sekolah yaitu SMAN 1 Narmada, SMAN 2 Narmada, MAS Hikmastussyarief NW Salut dan SMA NW Narmada.

Jenis penelitian ini adalah penelitian kuantitatif ex-post facto, yaitu jenis penelitian dimana variabel-variabel bebas telah terjadi ketika penelitian mulai dengan pengamatan variabel terikat dalam suatu penelitian. Sedangkan pendekatan data kuantitatif dapat diartikan sebagai jenis penelitian yang berlandaskan pada filsafat positifisme, digunakan untuk meneliti pada populasi atau sampel tertentu, pengumpulan data menggunakan instrumen penelitian, analisis data bersifat kuantitatif, dengan tujuan untuk menguji hipotesis yang telah ditetapkan (Sugiyono, 2017). Ditinjau dari alur analisis datanya rancangan penelitian yang digunakan adalah rancangan penelitian korelasi, karena ini untuk mengetahui hubungan keaktifan bertanya terhadap kecenderungan berpikir kritis.

Variabel penelitian yang digunakan pada penelitian ini yaitu variabel bebas dan variabel terikat. Keaktifan bertanya sebagai variabel bebas dan kecenderungan berpikir kritis sebagai variabel terikat. Populasi dalam penelitian ini adalah seluruh siswa kelas XI IPA di SMAN 1 Narmada, SMAN 2 Narmada, MAS Hikmatussyarief NW Salut dan SMA NW Narmada yang berjumlah 338 siswa.

Teknik pengambilan sampel (sampling) yang digunakan pada penelitian ini yaitu teknik Proportional Random Sampling, untuk menentukan sampel pada penelitian ini digunakan rumus Isaac dan Michael (Sugiyono, 2017) sehingga diperoleh 180 sampel atau 53\% dari populasi.

Instrumen penelitian yang digunakan pada penelitian ini yaitu lembar angket atau questionnaire yang terdiri dari angket keaktifan bertanya dan angket kecenderungan berpikir kritis. Kuisioner merupakan teknik pengumpulan data yang dilakukan dengan cara memberi seperangkat pertanyaan atau pernyataan tertulis kepada responden untuk dijawab (Sugiyono, 2017).

Uji validitas yang digunakan pada penelitian ini adalah uji validitas empiris. Validitas empiris dihitung menggunakan korelasi product moment Pearson. Uji reliabilitas instrumen menggunakan rumus alfa Cronbach, Uji prasyarat menggunakan uji normalitas dan linearitas sementara uji hipotesis menggunakan analisis regresi sederhana dan korelasi product moment Pearson (Sugiyono, 2017).

\section{HASIL DAN PEMBAHASAN}

Data penelitian ini diperoleh dari 180 sampel yang berasal dari siswa kelas XI IPA SMAN 1 Narmada, SMAN 2 Narmada, MAS Hikmatussyarief NW Salut dan SMA NW Narmada. Data yang dikumpulkan meliputi data angket keaktifan bertanya dan kecenderungan berpikir kritis menurut persepsi siswa.

Hasil perhitungan validitas dari angket keaktifan bertanya diperoleh 25 item pernyataan yang valid dari 35 item pernyataan dan untuk angket kecenderungan berpikir kritis diperoleh 45 item pernyataan yang valid dari 62 item pernyataan. Hasil uji coba instrumen untuk angket keaktifan bertanya dan kecenderungan 
berpikir kritis diperoleh nilai $\mathrm{r}_{\text {hitung }}$ sebesar 0,82 dan 0,89 dengan tingkat reliabelitas tinggi.

Tabel 2. Hasil Perhitungan Normalitas Data

\begin{tabular}{lcc}
\hline & $\begin{array}{c}\text { Keaktifan } \\
\text { Bertanya }\end{array}$ & KcBK \\
\hline $\begin{array}{l}\text { Chi-Kuadrat } \\
\text { Hitung }\end{array}$ & 10,54 & 9,88 \\
$\begin{array}{l}\text { Chi-Kuadrat } \\
\text { Tabel }\end{array}$ & 14,06 & 14,06 \\
\hline
\end{tabular}

Berdasarkan tabel tersebut diperoleh nilai Chi-Kuadrat hitung data keaktifan bectangkor dan kecenderungan berpikir kritis lebih kecil dari Chi-Kuadrat tabel maka data dikatakan terdistribusi normal.

Tabel 3. Hasil Uji Linearitas

\begin{tabular}{ccc}
\hline $\mathbf{F}_{\text {hitung }}$ & $\mathbf{F}_{\text {tabel }}$ & Keterangan \\
\hline$-4,72$ & 3,89 & Linear \\
\hline
\end{tabular}

Hasil yang diperoleh dari uji linearitas pada taraf signifikan 5\% menunjukkan nilai koefisien $\mathrm{F}_{\text {hitung }}=-4,72$ lebih kecil dari nilai koefisien $\quad \mathrm{F}_{\text {tabel }}=3,89$ sehingga dapat dikatakan bahwa keaktifan bertanya dengan kecenderungan berpikir kritis memiliki hubungan yang linear.

Tabel 4. Hasil Analisis Regresi Sederhana

\begin{tabular}{cccc}
\hline \multicolumn{2}{c}{ Nilai R } & Koefisien & Konstanta \\
\cline { 1 - 2 } $\mathrm{r}_{\text {hitung }}$ & $\mathrm{r}_{\text {tabel }}$ & & \\
0,3382 & 0,1455 & 0,146 & 44,55 \\
\hline
\end{tabular}

Hasil perhitungan regresi sederhana pada taraf signifikan 5\% dengan (dk pembilang $=1$ dan $\mathrm{dk}$ penyebut $=\mathrm{n}-2=180-2=178$ ) diperoleh $\quad r_{\text {hitung }}=0,3382$ lebih besar dari $r_{\text {tabel }}$ $=0,146$ artinya terdapat hubungan positif dan signifikan antara keaktifan bertanya dengan kecenderungan berpikir kritis $\mathrm{Y}=44,55+$ $0,146 X$.

Adapun skor rata-rata keaktifan bertanya dapat dilihat pada gambar 1 .

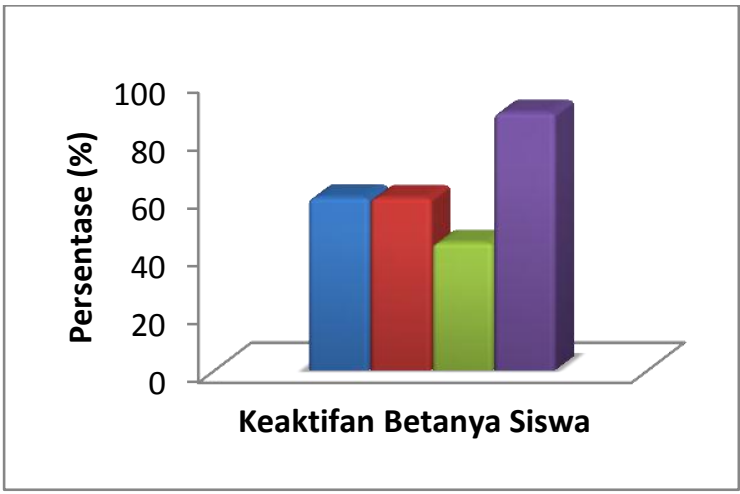

Gambar 1. Persentase Keaktifan Bertanya Siswa

Berdasarkan grafik di atas terlihat bahwa keaktifan bertanya siswa di SMAN 1 Narmada, SMAN 2 Narmada, MAS Hikmatussyarief NW Salut dan SMA NW Narmada, yaitu dengan persentase rata-rata secara berturut-turut sebesar 59.62\%, 59.52\%, $44 \%$ dan $88.89 \%$. Berdasarkan kriteria keaktifan bertanya pada tabel 3.8 maka keaktifan bertanya siswa berada pada interval skor $71 \leq \mathrm{x} \leq 85$ atau keaktifan bertanya pada keempat sekolah di kecamatan Narmada berada dalam katagori tinggi. Adapun tingkat keaktifan bertanya siswa tiap indikator di SMAN 1 Narmada, SMAN 2 Narmada, MAS Hikamatussyarief NW Salut, dan SMA NW Narmada dapat dilihat pada Gambar 2.

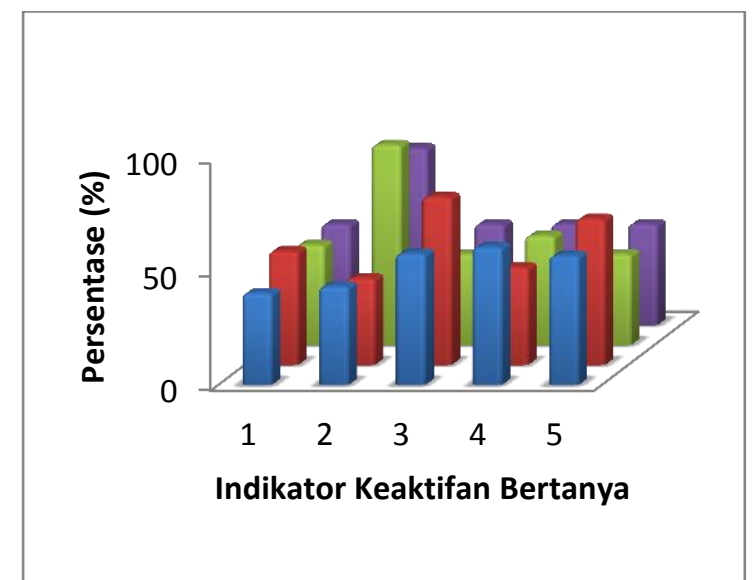

Gambar 2. Rata-Rata Keaktifan Bertanya Siswa Per Indikator

Keterangan:

- Indikator 1: Berani bertanya atau menyampaikan pertanyaan

- Indikator 2: Bertanya sesuai topik atau materi yang dipelajari

- Indikator 3: Percaya diri dalam mengajukan pertanyaan 


\section{Chemistry Education Practice,3 (1), 2020 - 9}

Zahranie, Andayani, Loka

- Indikator 4: Mengajukan pertanyaan secara jelas dan singkat

- Indikator 5: Mengajukan pertanyaan dengan bahasa yang tepat

Berdasarkan tabel diatas indikator mengajukan pertanyaan sesuai topik atau materi yang sedang dipelajari memiliki tingkat keaktifan tertinggi dengan persentase sebesar $48.33 \%$ dan indikator berani bertanya memiliki tingkat keaktifan terendah dengan persentase sebesar $39.44 \%$. Hal ini menunjukkan bahwa siswa memiliki tingkat ketertarikan dan rasa ingin tahu yang besar pada materi yang sedang dipelajari sehingga menimbulkan pertanyaan terhadap materi tersebut. Sedangkan siswa memiliki keberanian yang cukup untuk mengajukan pertanyaan. Oleh karena itu, guru perlu meningkatkan keberanian siswa dalam mengajukan pertanyaan di dalam kelas dengan memotivasi siswanya agar terbiasa bertanya, karena hal itu penting bagi perkembangan kepriadian dan penambah pengetahuan. Adapun skor rata-rata kecenderungan berpikir kritis dapat dilihat pada gambar 3 .

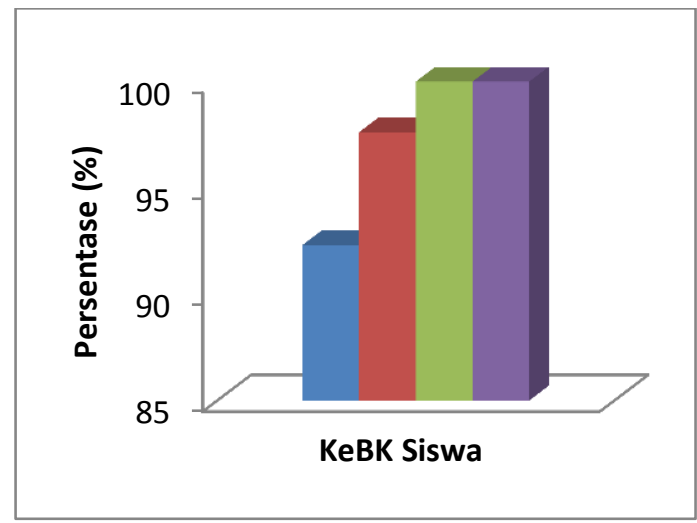

Gambar 3. Persentase Kecenderungan Berpikir Kritis Siswa Kelas XI IPA di SMA/MA Se-

Kecamatan Narmada

Berdasarkan grafik di atas menunjukkan bahwa tingkat kecenderungan berpikir kritis di SMAN 1 Narmada, SMAN 2 Narmada, MAS Hikmatussyarief NW Salut, dan SMA NW Narmada berada dalam katagori medium dengan persentase secara berturut-turut yaitu $92.31 \%$, $97.62 \%, 100 \%$ dan $100 \%$. Berdasarkan kriteria kecenderungan berpikir kritis pada tabel 3.6 maka kecenderungan berpikir kritis siswa berada pada interval 157-221 atau kecenderungan berpikir kritis siswa pada keempat sekolah berada dalam katagori medium. Adapun tingkat kecenderungan berpikir kritis siswa tiap indikator di SMAN 1 Narmada, SMAN 2 Narmada, MAS Hikamatussyarief NW Salut, dan SMA NW Narmada dapat dilihat pada Gambar 4.

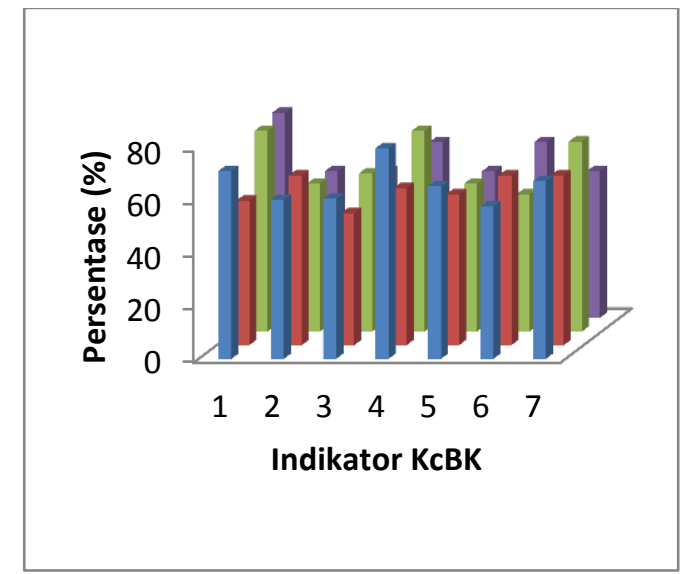

Gambar 4. Grafik Rata-Rata Kecenderungan Berpikir Kritis Siswa Per indikator

Keterangan:

- Indikator 1: Truth-seeking

- Indikator 2: Open-mindedness

- Indikator 3: Analyticity

- Indikator 4: Systematicity

- Indikator 5: Self-confidence

- Indikator 6: Inquisitiveness

- Indikator 7: Maturity

Indikator tertinggi berada pada indiktor Self-confidence, dimana indikator ini menunjukkan bahwa siswa memiliki tingkat kepercayaan yang tinggi.Sedangkan untuk indikator rendah berada pada indikator Analyticity, dimana siswa masih kurang memiliki kemampuan untuk menggunakan fakta dalam menyelesaikan masalah, mengantisipasi potensi kesulitan terhadap konsep yang dimana ini dapat dilakukan dengan mengajukan pertanyaan untuk mendapatkan suatu informasi.

Adapun persamaan regresi sederhana yang diperoleh dari perhitungan analisis regresi yaitu $\mathrm{Y}=44,55+0,146 \mathrm{X}$, lebih jelasnya dapat dilihat pada gambar 5 . 


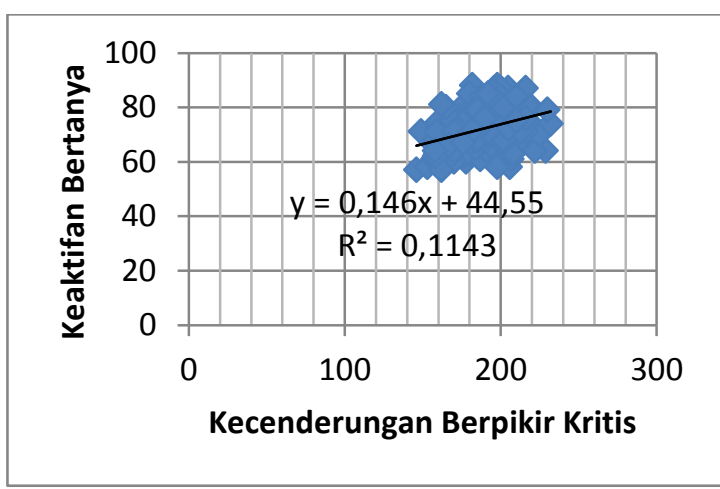

Gambar 5. Grafik Persamaan Regresi

Sederhana Kecenderungan Berpikir Kritis Terhadap Keaktifan Bertanya

Bertanya merupakan cara sesorang untuk mencari jawaban kepastian terhadap apa yang belum dipahaminya, sehingga bertanya merupakan keterampilan dasar yang harus dimiliki oleh siswa. Keaktifan bertanya siswa pada penelitian ini hanya memberikan kontribusi untuk beberapa indikator kecenderungan yaitu Open-mindedness, Analyticity, Self-confidence dan Inqusitiveness. Siswa yang memiliki pemikiran terbuka akan bersedia mendengar dan menerima pendapat dari orang lain. Salah satu cara seseorang untuk menerima pendapat orang lain adalah bertanya, karena dengan bertanya siswa akan menerima ide, pandangan, argument, teori dan juga kesimpulan dari apa yang ditanyakannya untuk mendapatkan sebuah jawaban kepastian. Siswa dikatakan memiliki kemampuan analisis, apabila siswa tersebut bisa memecahkan suatu permasalahan. Salah satu cara seseorang dalam menyelesaikan permasalahan adalah melalui bertanya, sebab dengan mengajukan pertanyaan siswa bisa tahu betul seluk beluk dari permasalahan yang akan dipecahkan. Siswa dikatakan percaya diri dalam berpikir kritis apabila siswa tersebut menunjukkan sikap percaya diri atas kemampuan yang dia miliki. Sehingga apabila seseorang memiliki kepercayaan diri yang tinggi, maka siswa tersebut akan mempunyai keyakinan dan keberanian untuk berbuat atau melakukan sesuatu. Bertanya merupakan cara siswa untuk mengasah keberanian dan kepercayaan diri yang dimilikinya. Faktor yang mendorong siswa mengajukan pertanyaan adalah rasa ingin tahu atau rasa percaya diri yang dimilikinya. Sebab siswa yang memiliki rasa ingin tahu yang tinggi cenderung memiliki tingkat berpikir kritis yang tinggi (Laelasari, 2018).
Siswa dikatakan memiliki rasa ingin tahu apabila sikap yang dilakukan menunjukkan rasa ingin tahu terhadap sesuatu atau isu yang berkembang. Hal ini biasanya diaktualisasikan dengan bertanya dan juga menyimak dengan tekun langkah-langkah berpikir yang diungkapkan temannya. Menurut Sari, dkk (2008) hasrat ingin tahu manusia terpuaskan jika memeroleh pengetahuan mengenai hal yang dipertanyakan. Jadi, jika seseorang mengajukan pertanyaan, hal tersebut menunjukkan kebutuhan tentang jawaban yang diinginkan berdasarkan rasa ingin tahu yang dimilikinya. Dengan begitu rasa ingin tahu yang timbul melalui pertanyaan dapat mencerminkan bahwa siswa tersebut memiliki kecenderungan berpikir kritis (Hughes, 2003). Hal ini sesuai dengan penelitian yang dilakukakan oleh Requistiawati (2017) yang mengatakan bertanya merupakan cara seseorang menggali informasi, dapat merangsang keingintahuan anak, menstimulus imajinasi anak, cakap dalam penyelesaian masalah, dan memotivasi anak untuk memperoleh pengetahuan yang baru dari jawaban orang lain.

Hasil yang diperoleh dari perhitungan koefisien korelasi yaitu $r_{\text {hitung }}=0,3382$. Berdasarkan tabel interpretasi koefisien korelasi tersebut maka keaktifan bertanya dengan kecenderungan berpikir kritis memiliki hubungan yang rendah, artinya keaktifan bertanya tidak memberikan pengaruh ynag besar terhadap kecenderungan berpikir kritis. Koefisien determinasi keaktifan bertanya terhadap kecenderungan berpikir kritis pada penelitian ini sebesar $r^{2} \times 100 \%=0,3382^{2} \times$ $100 \%=11,43 \%$ dan sisanya $88,57 \%$ dipengaruhi oleh faktor lain yang tidak diteliti pada penelitian ini. Kecenderungan berpikir kritis pada dasarnya dipengaruhi oleh beberapa faktor yang saling terkait, baik yang bersal dari dalam diri siswa maupun lingkungan keluarga. Faktor-faktor yang dimakud misalnya minat belajar, konsentrasi belajar, intensitas bimbingan belajar oleh orang tua, intensitas mengikuti organisasi, intensitas membaca, dan kecerdasan anak. Hal ini diperjelas oleh penelitian yang dilakukan Susilo (2010) terdapat pengaruh konsentrasi belajar dan intensitas bimbingan belajar orang tua terhadap kecenderungan berpikir kritis siswa.

\section{KESIMPULAN}

Berdasarkan hasil penelitian dan pembahasan yang telah diuraikan, maka dapat disimpulkan bahwa: Tingkat keaktifan bertanya 
siswa kelas XI di SMA/MA se-kecamatan Narmada berada dalam katagori tinggi dan tingkat kecenderungan berpikir kritis siswa kelas XI di SMA/MA se-kecamatan Narmada berada dalam katagori medium. Adapun kontribusi keaktifan bertanya terhadap kecenderungan berpikir kritis sebesar 11,43\%. Terdapat hubungan yang positif dan signifikan antara keaktifan bertanya dengan kecenderungan berpikir kritis siswa kelas XI IPA di SMA/MA se-kecamatan Narmada tahun ajaran 2019/2010.

\section{SARAN}

Hasil penelitian menunjukkan bahwa terdapat hubungan antara kecenderungan keaktifan bertanya dengan kecenderungan berpiki kritis dalam konstribusi yang kuat. Namun, faktor ini tidak dapat diabaikan khususnya oleh guru. Guru perlu berupaya lagi untuk meningkatkan kecenderunga berpikir kritis siswa sebab masih dalam katagori medium untuk meningkatkan keaktifan bertanya yang tinggi sehingga dapat menyebabkan kemampuan berpikir kritis siswa yang tinggi melalui pemilihan model pembelajarn yang cocok serta menciptakan suasana belajar yang aktif.

\section{DAFTAR PUSTAKA}

Andayani, Y. 2018. The Correlation Of Prospective Teachers' Tendency Of Critical Thinking and Their Critical Skills Toward Theirs Learning Outcomes. "Unnes Science Education Journal". 7 (2): 229-233.

Facione, A. 2011. Critical Thinking: What It Is and Why It Counts. Measured Reasons and The California Academic Press, Millbrae, CA.

Hughes, A. G dan E.H. Hughes. 2003. Learning \& Teaching. New Delhi: Sonali Publications. Terjemahan Oleh SPA Teamwork Yogyakarta.

Laelasari, I., Yusuf, H.A. 2018. Mengeksplorasi Kemampuan Berpikir Kritis dan Rasa Ingin Tahu Siswa Melalui Kegiatan Laboratorium Inquiry Sederhana. Jurnal THAIBIEA. 1(1): 14-19.

Mayasari, T. Kadarohman, A. Rusdiana, D dan Kaniawati. 2016. Apakah Model Pembelajaran Problem Based Learning dan Project Based Learning Mampu Melatih Keterampilan Abad 21?. JFFK. 2 (1). 48-55.

Ramdani, D dan Badriah, L. 2018. Korelasi Antara Kemampuan Berpikir Kritis
Dengan Hasil Belajar Siswa Melalui

Model Pembelajaran Inkuiri

Terbimbing Berbasis Blended

Learning Pada Materi Sistem Respirasi

Manusia. Jurnal Bio Educatio. 3 (2): 37-44.

Requistiawati. 2017. Profil Keterampilan Bertanya Siswa Pada Pembelajaran IPA SMP Global Madani Bandar Lampung Tahun Pelajaran 2016/2017: Skripsi.

Royani, M dan Muslim, B. 2015. Keterampilan Bertanya Siswa SMP Melalui Strategi Pembelajaran Aktif Tipe Team Games Quiz Pada Materi Segi Empat. Jurnal Pendidikan Matematika. 1 (2): 1-7.

Sugiyono. 2017. Statistik Untuk Penelitian. Bandung: Alfabeta.

Sari, D.M dan Apriyani, F. 2008. Rasa Ingin Tahu Adalah Kodrat Manusia. Semarang: Universitas Negeri Semarang.

Susilo, A. 2010. Konsentrasi Belajar dan Intensitas Bimbingan Belajar Orang Tua Pengaruhnya Terhadap Kecenderungan Berpikir Kritis Siswa Kelas VIII SMP Negeri 2 Delanggu Kabupaten Klaten Tahun Pelajaran 2009/2010. Jurnal Pendidikan Kewarganegaraan. 1 (1): 1-8. 